\title{
What Explains Our Slow Economic Growth? Causality Analysis between Economic Growth and Defense Spending in Pakistan
}

\author{
Sabeen Anwar \\ Department of Economics, The Institute of Business Management (IOBM), Karachi. \\ Korangi Creek, Karachi , Pakistan \\ Email: sabeen.anwer29@gmail.com
}

Received date: 31 August 2016; Accepted date: 27 March 2017; Published date: 15 May 2017

Academic Editor: Aqilah Nadiah Md Sahiq

Copyright @ 2017. Sabeen Anwar . Distributed under Creative Commons CC-BY 4.0

\begin{abstract}
Pakistan is faced with budget deficits, high unemployment and slow growth. This study provides a link between defense spending, debt servicing, development expenditures and economic growth for Pakistan. We examine whether there is a causality between defense expenditures and debt servicing on the one hand and economic growth on the other during the period 19882011, using Toda Yamamoto-Modified Standard Granger Causality technique. The unidirectional causality found between economic growth-defense spending and debt servicing - economic growth while bidirectional causality is found between development expenditure-economic growth and between current expenditure-economic growth. Research suggested to be selfsufficient in domestic defense industry which leads to curtail in import budget and it will create employment resources and funds will available for developing programs.
\end{abstract}

Keywords: Causality, Economic Growth, Defense Spending, Toda-Yamamoto.

JEL code: H5, 04.

\section{Introduction}

Less Developed Countries (LDCs) often face the criticism that heavy defense spending slows economic growth. That spending on non-productive activities has insignificant impact on economic growth. Moreover, defense spending absorbs a large

Cite this Article as: Sabeen Anwar (2017), "What Explains Our Slow Economic Growth? Causality Analysis between Economic Growth and Defense Spending in Pakistan ", Journal of Economics Studies and Research, Vol. 2017 (2017), Article ID 280356,DOI: 10.5171/2017.280356 
proportion of financial resources of these countries. However, spending on defense may have other geopolitical considerations. When a hungry and poor country has to choose between bread and butter or gun which one should it opt for? The former is required for filling up the belly, but the latter is required for survival. If the country opts to allocate more resources to defense, it will have less resources available for civilian consumption. However, it may be argued, that unless you are protected, how can you enjoy the civilian goods and services? For example, if the law and order is bad, can high economic growth become a reality?

The military expenditure is an extremely important part of any country. It shows how much a country feels vulnerable to the outside world. There has an upward trend in the defense expenditure, especially after the World War II and the significant change in the geopolitical scenario. Over the last fifteen years, It is highly observed declining trend followed by development expenditure because of huge defense expenditure in comparison with health, education and other developing expenditure, defense spending stands with higher percentage. In Pakistan, on average GDP growth consists of 5.06 percent, inflation 8.80 percent and saving 15.11 percent. (Economic Survey of Pakistan, 2012, 2013). Furthermore, defense spending for fiscal year 2014-15 was 11.6 percent and now in fiscal year 2016, it is announced 11 percent. .

Although the behaviour of increasing defense expenditure around the world can be tackled by argument of internal and external security, threats and fighting terrorism, the way arms related spending is rising is suspicious . World's Defense spending in 2007 was $\$ 1339$ billions which is 2.5 percent of the world's GDP (SIPRI, 2008). During 1998 to 2007, defense spending increased by 45 percent in real term because of the second world war and after 9/11 terrorist attack in USA (Agostino and Dunne and Pieroni, 2010).

According to UNDP, Pakistan ranked 145 out of 187 countries in terms of human development index (HDI). Furthermore, multidimensional poverty index (MPI) explored numerous deprivations in education, health and living standard. The UNDP (2011) indicated in a report approximately 50 percent Pakistanis are suffering from multiple deprivations and 11 percent vulnerable to multiple deprivations (Kalim and Hassan).

When there is a very low literacy rate, unavailability of basic necessities, and declining medical facilities, then on average 4.88 percent on defense which is almost 10 times larger as compared to education expenditure and health sectors, which is truly a luxury that costs Pakistan substantially.

The direction of causation between economic growth and defense spending is not predicted theoretically. However, there are two opposing views. First the Keynesian-type argument that changes in aggregate demand brings fluctuations in the level of income, output and employment. Aggregate demand created by increase in defense spending leads to increase in the development of the infrastructure and creates more employment opportunities. There is, therefore, a positive relationship between economic growth and defense spending. The way defense spending leads to higher economic growth (Keynesian notation) is shown in Figure 1.1. Figure 1.2 shows the spin-off effect while Figure 1.3 shows inflation and consumption effects. The second view argues that creation of employment through defense spending is very small because most of LDCs expenditure on defense consists of buying weapons from abroad. 


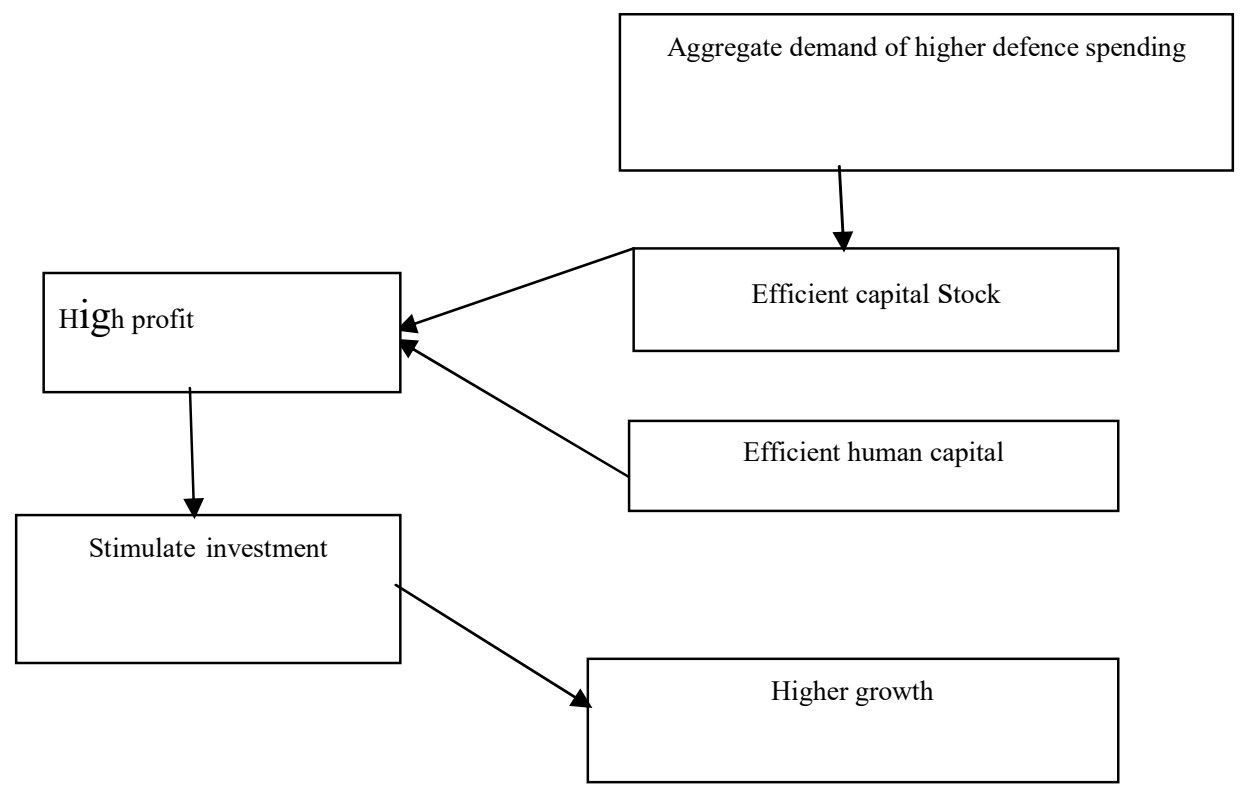

Figure 1.1 : Growth in the economy through higher defense spending (Keynesian notation)

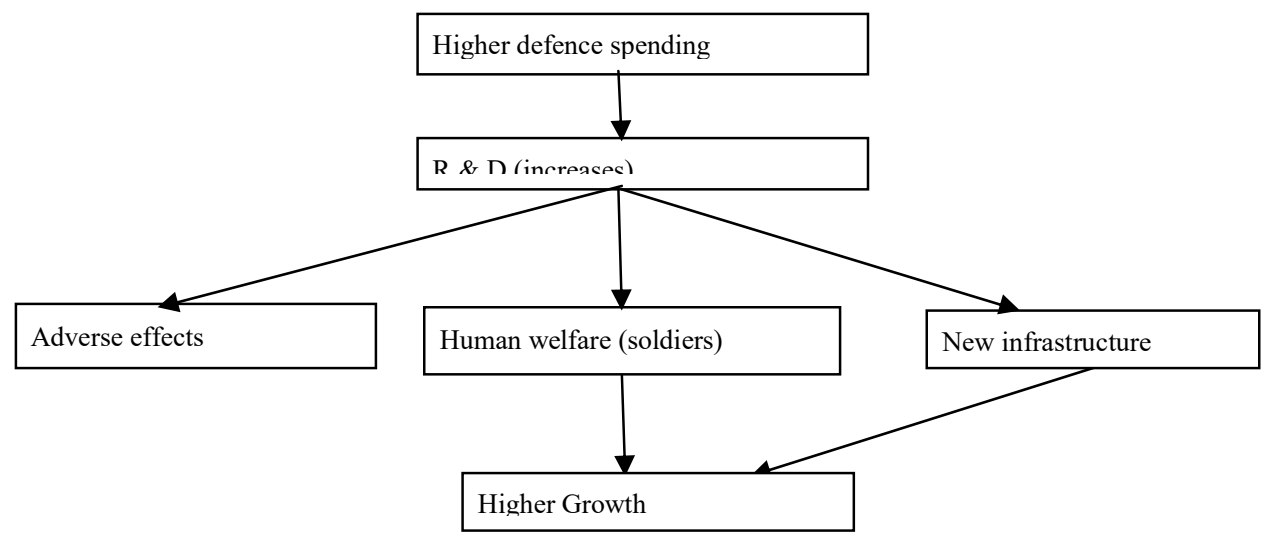

Figure 2.1: Growth in the economy through higher defense spending (spin-offs effect) 


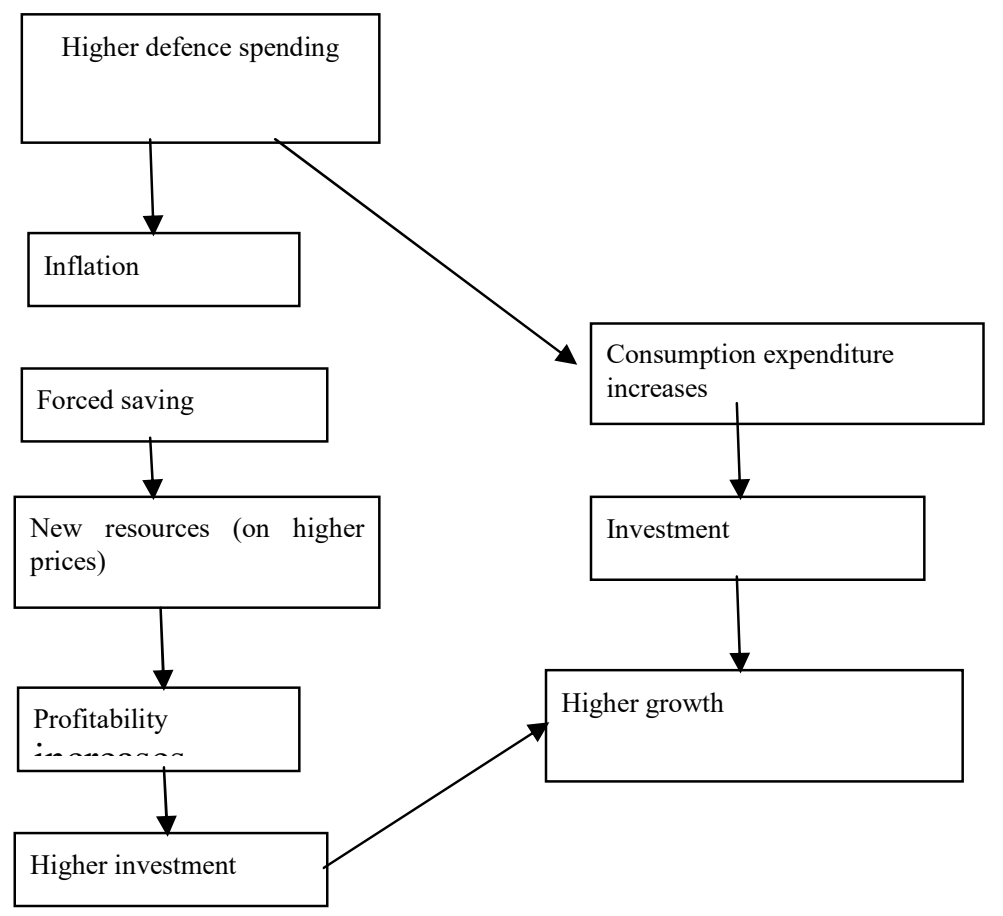

\section{Figure 3.1: Growth in the economy through higher defense spending (inflation \& consumption effects)}

The areas of research on defense spending and economic growth can be divided into three parts:

1. The relationship between defense spending and economic growth.

2. Causality between defense spending and economic growth.

3. Political stability/instability's link with defense spending and economic growth

The present study deals with causality between defense spending, debt servicing and development expenditures and economic growth in the case of Pakistan. Section 2 reviews the existing literature; Section 3 gives a brief overview of Pakistan's economy with emphasis on defense, development and debt servicing expenditures. Section 4 analyses the data and methodology, while conclusions and policy implications are presented in Section 5.

\section{Literature Review}

Al-Jarrah (2005), using the Johansen's cointegration procedure, Standard Granger Causality and VECM reports the presence of cointegration between economic growth and defense spending in the Saudi Arabian economy for the period of 1970-2003, bidirectional causality with real GDP and unidirectional causality with non-oil real GDP. AL-JARRAH recommended reduction in defense expenditure for making more financial resources for education, health and other essential economic and social activities. 
Künü, Hopoğlu and Bozma (2016), a panel analysis of twelve Middle Eastern countries, i.e. United Arab Emirates, Saudi Arabia, Iran, Israel, Jordan, Lebanon, Oman, Turkey, Bahrain, Egypt, Kuwait and Yemen during the period 1998-2012 found the negative relationship between economic growth and defense spending, whereas external conflict and FDI are positively related to economic growth.

Farhani (2016), a time series analysis in case of India during 1970-2012, found the relationship between external debt and military spending. Auto-Regressive Distributed Leg (ARDL), Vector Error Correction Model (VECM) and Granger Causality Test, explored that defence spending and economic growth are causing external debt. Empirical finding suggested the Indian government to reduce military expenditure.

Habibullah, et al (2008) panel and time series analyses for twelve Asian countries, Bangladesh, China, India, Indonesia, Japan, Malaysia, Philippines, Singapore, Sri Lanka, Thailand, Pakistan, South Korea for the period 1989 to 2004 used unit root, cointegration and error-correction technique. Empirical results from the panel suggested that economic growth and defense expenditure are not related to each other. However, there is a long run relationship and a causal relationship between economic growth and military expenditure. Whereas, in the time series analysis, defense spending and real GDP per capita are integrated of order one.

For Pakistan Khilji and Mahmood's (1997) study for the period 1972-1995, using Granger causality results, they found bidirectional causality between defense expenditure and economic growth. Their result reveals that defense expenditure and GDP growth are negatively related to each other. In the single equation model defense ratio is positively affected by the saving ratio and negatively affected by the inflation rate.
In Farzanegan's (2012) study for Iran for the period 1959-2007 using Impulse Response Functions (IRF) and Variance Decomposition Analysis (VDA), Granger causality analysis reveals unidirectional causality between growth rates of military expenditure and GDP. The response of income growth to increasing shocks in the military budget is positive and statistically significant.

Pradhan (2010) studied five Far Eastern Asian countries: Philippines, Malaysia, Indonesia, Thailand and Singapore over the period of 1988-2007. Empirical analysis at the individual level and panel level is based on cointegration and causality tests. The author finds unidirectional causality from economic growth and defense spending in Malaysia, Indonesia, Thailand and Singapore and bidirectional causality for the panel of five Asian countries. However, there is feedback between defense spending and economic growth in the Philippines at the individual and panel level. Moreover, neither defense spending nor economic growth can be considered as exogenously determined. Furthermore, the long run relationship between economic growth and defense spending exists at the individual level and for the panel.

Dimitraki and Liu ( 2011) for China for the period of 1950-2011used the augmented Dickey-Fuller test, the Breusch- Pagan test, Engle ARCH test and the Breusch-Godfrey LM test. Empirical results suggested military spending has an overall net positive influence on economic growth. Moreover, the magnitude of the positive impact tends to increase over time. Furthermore, China's military spending is via the Keynesian effect (expansion of aggregate demand) leading to government capital allocation in such a way that enhances employment and profits in the Chinese economy, which in turn leads to increase in investment which has an overall positive impact on economic growth. 
Hasan (2004) tried to use defense expenditure as a macroeconomic stabilization tool in the case of Pakistan for the period of 1951-2003. The annual time series data analyzed using Johansen's cointegration and granger causality techniques on the variable, namely, defense spending, development expenditure, CPI, GDP and income. Results found long run relationship and bidirectional causality among the variables. Furthermore, long run economic growth is not hurt by defense spending. However, defense expenditure does not significantly explain GDP and inflation dynamics in the short run. Furthermore, long run and short run causality suggested Military Keynesian Hypothesis (MKH) does not hold over the period of the study.

Pradhan's (2010) case study of four Asian countries, namely, Pakistan, India, Nepal and China over the period of 1988-2007 at the individual country level and panel for four Asian nations. The study uses integration and co-integration techniques and Granger causality test. He finds cointegratin between defense spending for the four Asian countries. In the cointegration framework there is a long run relationship between defense spending and economic growth at the individual level and for the panel for the four Asian nations, implying that defense spending of a country can affect the defense spending of other countries. Moreover, there is a bidirectional causality between China and India; unidirectional causality from defense spending to economic growth in China and Nepal, unidirectional causality from economic growth to public debt in Pakistan and unidirectional causality from public debt to defense spending in India. There is short run bidirectional causality between public debt and economic growth at the panel level for the four Asian countries.

Shenggen Fan and Saurkar (2003) analyse government expenditure of 44 developing countries with the help of macroeconomic variable for the period 1980 to 2002 . Their results suggest that governments should curtail their expenses on non-productive sectors such as defense.

Looney and Frederickson (1990), empirical analysis of six East Asian countries, namely Singapore (1965-85), Malaysia (19601986), Philippines, Thailand, South Korea and Indonesia suggested expected increase in GNP to increase in defense budget.

Brasoveanu (2010) used cluster analysis, quintile analysis and regression techniques and Granger causality in the case of Romania for the period of 1998 to 2007. The Empirical analysis suggested a negative correlation between defense expenditure and economic growth (GDP). However, according to the Granger causality test economic growth does not cause defense expenditure in the case of Romania.

Dunne (2010) analysed the economic effect on military spending in Sub Saharan Africa (SSA) for the period of 1988 to 2006 with the help of growth models. The result suggested unequivocal negative impacts of military spending on economic growth in Sub Saharan Africa (SSA).

Dunne (2009) provides a review of research based on the link between arms spending and economic growth for developing countries. The Empirical analysis suggested no evidence for a positive effect of military spending on economic growth in the case of developing countries the study found a negative effect of arms spending on economic growth for selected developing countries for the period. The authors suggested reducing arms and military spending for the increasing economic growth.

Cholifihani (2008) analysed long run and short run relationship between debt servicing and economic growth for Indonesia during 1980 to 2005 and found debt overhanging in the long term and increase in public external debt servicing causing slowdown in economic growth. 
However, in the short run, Indonesia did not face debt overhang.

Shah and Pervin (2012) investigated the effect of debt stock and debt service for Bangladesh during 1974 to 2008. Results suggested positive effects of debt stock and an adverse effect of debt servicing on economic growth. Shabbir's (2008) case study for 24 developing countries tried to explore the relationship between economic growth and external debt and found external debt stock adversely affecting economic growth.

Time series analyses for Nigeria from the period 1970-2007 by Ogunmuyiwa (2011) revealed no causality between external debt and economic growth. However, causation between the variables was weak. Dandan (2011) found government expenditure to have a positive impact on aggregate economic growth in the period 1990 to 2006 for Jordan, which is compatible with Keynesian fiscal theory. He recommended that human capital should have a higher priority.

Using Granger causality analysis, Dogan (2006) studied government expenditure and national income for five Asian countries i.e. Indonesia, Malaysia, Philippines, Singapore, and Thailand for the last four decades (1960 to 2002). The author found that government expenditure does not have a significant impact on economic growth.

Rehman, Iqbal, Siddiqi (2010) analysed the nature and direction of causality between public expenditure and national income in Pakistan for the period 1971 to 2006. Their results supported Wagner's Law as they found unidirectional causality between GDP and public expenditure. However, at a disaggregate level GDP only causes administrative expenditure as no causality is found between development expenditure, debt servicing and defense expenditure. Empirical analysis cannot support the Keynesian hypothesis at the aggregate or disaggregate levels.

Fan and Rao (2003) found mix performance between government spending and economic growth in forty three developing countries during the period 1980 to 2002. Sevitenyi (2012) analysed the relationship and direction of causality between economic growth and government expenditure in Nigeria during the period 1961 to 2009. The Results support the Keynesian hypothesis as the author found unidirectional causality between economic growth and government expenditure. However, there is no support for Wagner's law in Nigeria both at the aggregate and disaggregated levels.

Zaman, Shah, M. Khan, Ahmad, 2012 found external debt is negatively related to economic growth whereas it has a statistically significant positive relationship to military expenditure in the short run. SAARC external debt in the short and longrun have a significant positive relationship to military expenditure. The relationship is elastic in the long-run, but inelastic in the short-run.

Shahbaz, Afza a \& Shabbir; 2012 ,corroborated with the view by Abu-Bader and Abu-Qarm (2003) who found that a rise in government non-military spending will stimulate the pace of economic growth and in turn, the government allocates more resources to productive and efficient ventures to sustain the rate of economic growth. The study explored that defense expenditure financed by borrowing and budget deficit will lead to increase in interest rates causing inflation and makes the government non-military spending less efficient and expensive.

Kalim and Hassan, the study revealed military expenditure exerts positive and significant impact on poverty. For example, one unit increase in defense expenditure leads to increase in poverty by 0.44 . The inherent justification may be that the 
defence expenditure in Pakistan may be done at the expense of development expenditure and thus may have a negative impact on economic growth in Pakistan as the studies by Smith (1980) and Dunne (1996) have found a negative relationship between defense spending and economic growth for the case of developing countries. It is evident from the results that poverty lagged by one year accentuates poverty in the current year. It is quite possible that because defense expenditure on social development is hampered, poverty accelerates.

Haseeb, Bakar, Azam, Hassan \& Hariyatie, (2014) elaborated that economic growth and the defense expenditure are negatively related, and savings have a positive impact on economic growth. Therefore, one (1) percent increase in defense expenditure causes a 0.57 percent decrease in economic growth and one percent increase in saving causes 0.73 percent increase in economic growth. The Study suggested defense expenditure must be financed by borrowing and increasing the money supply, and at the same time reducing other social and public expenditures. This scenario is the cause of the inflation eroding the savings real worth and eventually leading to a decrease in it, investments are also affected and in turn they further affect economic growth.

Tekeoglu (2008) suggested military regimes most dominate with less open trade or in some cases closed economy and tighter controls over markets, whereas democratic governments highlighted with free market features and open trade policies. (Heo, 1998). Spending on defense budget could change as it depends on the country's regime and consequently affecting efficiency and effectiveness. Moreover, Heo (1998) was not able to find any valid and systematic pattern in the relationship between regime type and the economic effects of defense spending on growth.
On the contrary , Na Hou (2009) stated that India's higher and increasing military spending is the cause of Pakistan higher spending on arms and it shows the existence of rivalry and arms race between the two countries.

Agostino , Dunne and Pieroni, 2010, explained the state is mature enough to create an equilibrium between the opportunity cost and security benefits or military spending in order to achieve national interests which achieve the optimal social welfare.

On the opposite side, Keynesian states that the state, in order to improve macroeconomic stability in the economy, uses military spending which increases output, via multiplier effect. It leads to more $R \& D$, increased capacity utilization. However, it has failed to consider the supply side factors.

\section{Pakistan's Defense Budget}

In fiscal budget 2012-13, the Government of Pakistan allocated additional Rs.50 billion for the defense budget. According to official defense budget documents for fiscal year 2012-13, about $10 \%$ or nearly Rs.545 billion (about \$5.82) compared with Rs.495 billion in 2011-12 was allocated for defense. Furthermore, actual defense spending for fiscal year 2011-12 was Rs.509.32 billion (about $\$ 5.45$ billion) or Rs.14.32 billion more than the allocation for 2011-12. The main cause of Pakistan's defense budget deficit is the reduction in US defense aid. Table 1 \& Figure 2.1 shows defense expenditure by South Asian countries as a percentage of their GDP during 1988-2010.

Pakistan's economy has passed through many critical challenges such as the sharp rise in food and oil prices combined with natural disasters in 2010 and 2011. Governance and security issues pose the most serious challenges to achieving decent growth rates and investment to GDP which was the lowest for 37 years. In 2011-12, 
Pakistan's economy grew by 3.7 percent against the targeted growth rate of 4.2 percent. The country faces high public debt and the rate of inflation was double-digit for the last five years. Pakistan's defense and debt servicing expenditures have declined during the last two decades. Debt serving consumed about 39.9 percent of total revenues. During the last fiscal year the country's public debt stood at Rs.856 billion, while debt servicing stood at Rs.1, 024 billion out of which Rs 821 billion was on account of domestic debt servicing. During the Musharraf era, Pakistan's total public debts increased from Rs 3,200 billion to Rs 6,700 billion. "The present government has pushed the tally to Rs 12,800 billion. Figure 2.3 shows the trend in debt servicing on external debt as a percent of GDP due to which new development projects could not be initiated

Table 1: Defense Expenditure by South Asian Countries as Percentage of GDP 1988-2010

\begin{tabular}{|l|l|l|l|l|l|}
\hline Year & Pakistan & India & Nepal & Bangladesh & $\begin{array}{l}\text { Sri } \\
\text { Lanka }\end{array}$ \\
\hline 1988 & 6.2 & 3.6 & 0.9 & 1 & 2.4 \\
\hline 1989 & 6 & 3.5 & 1 & 1.1 & 1.8 \\
\hline 1990 & 5.8 & 3.2 & 0.9 & 1 & 2.3 \\
\hline 1991 & 5.8 & 3 & 0.9 & 1 & 3.1 \\
\hline 1992 & 6.1 & 2.8 & 0.9 & 1.1 & 3.4 \\
\hline 1993 & 5.7 & 2.9 & 0.9 & 1.2 & 3.4 \\
\hline 1994 & 5.3 & 2.8 & 0.9 & 1.2 & 3.7 \\
\hline 1995 & 5.3 & 2.7 & 0.8 & 1.3 & 5.9 \\
\hline 1996 & 5.1 & 2.6 & 0.8 & 1.3 & 5.5 \\
\hline 1997 & 4.9 & 2.7 & 0.8 & 1.3 & 4.6 \\
\hline 1998 & 4.8 & 2.8 & 0.8 & 1.3 & 4.5 \\
\hline 1999 & 3.8 & 3.1 & 0.9 & 1.3 & 4 \\
\hline 2000 & 3.7 & 3.1 & 0.8 & 1.3 & 5 \\
\hline 2001 & 3.8 & 3 & 1.1 & 1.2 & 4.3 \\
\hline 2002 & 3.9 & 2.9 & 1.3 & 1.1 & 3.3 \\
\hline 2003 & 3.7 & 2.8 & 1.5 & 1.1 & 2.9 \\
\hline 2004 & 3.6 & 2.8 & 1.6 & 1.1 & 3 \\
\hline 2005 & 3.4 & 2.8 & 1.7 & 1 & 2.6 \\
\hline 2006 & 3.3 & 2.5 & 1.6 & 1 & 3.8 \\
\hline 2007 & 3 & 2.3 & 1.4 & 1 & 3.7 \\
\hline 2008 & 2.8 & 2.6 & 1.3 & 1 & 1.1 \\
\hline 2009 & 2.8 & 2.9 & 1.4 & 1.1 & 3.6 \\
\hline 2010 & 2.8 & 2.7 & 1.4 & & \\
\hline
\end{tabular}

Source: SIPRI 


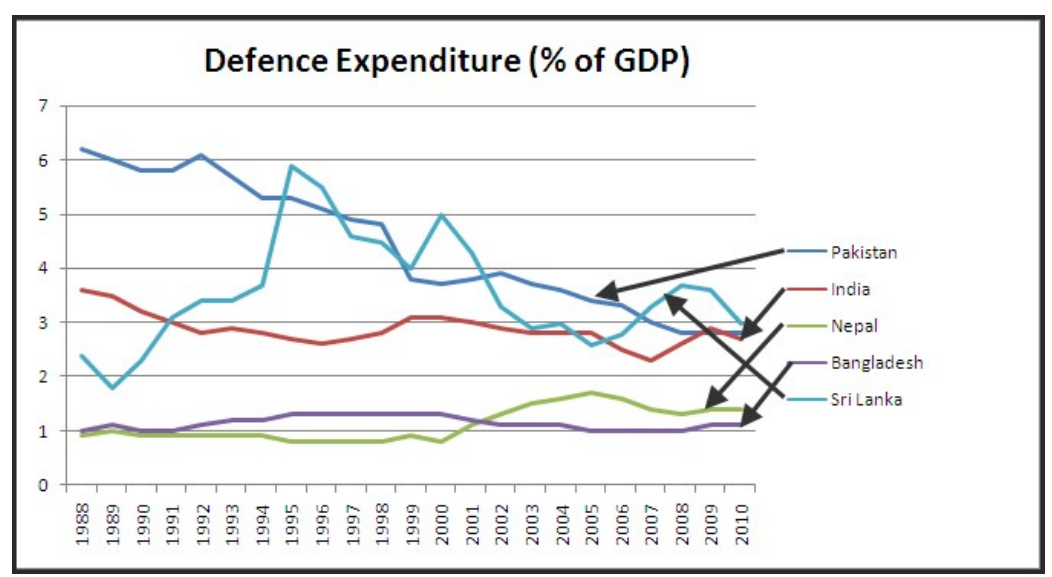

Figure 2.1: Defense Expenditure by South Asian Countries as Percentage of Gross Domestic Source: SIPRI. Product (constant 2000 US\$) 1990-2010.

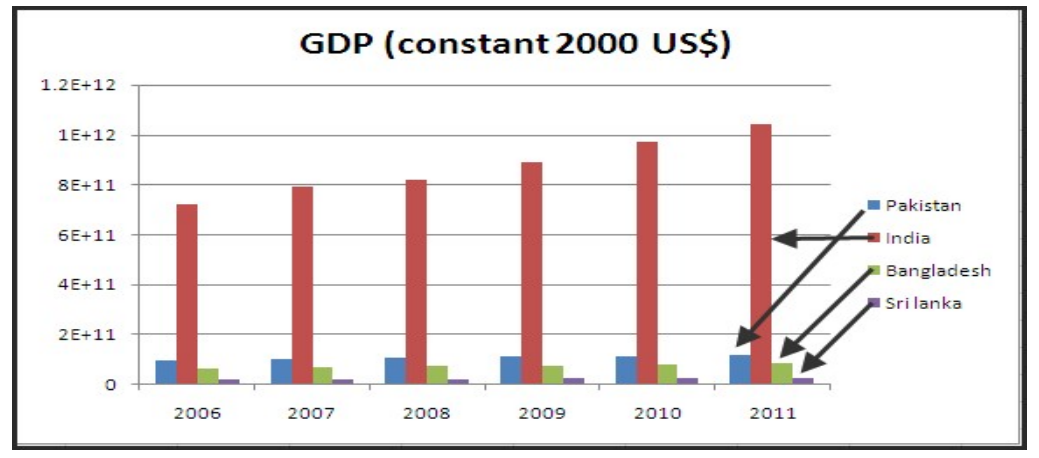

Figure 2.2: Gross Domestic Product by South Asian Countries (constant 2000 US\$) 19902011

Source: WDI. 


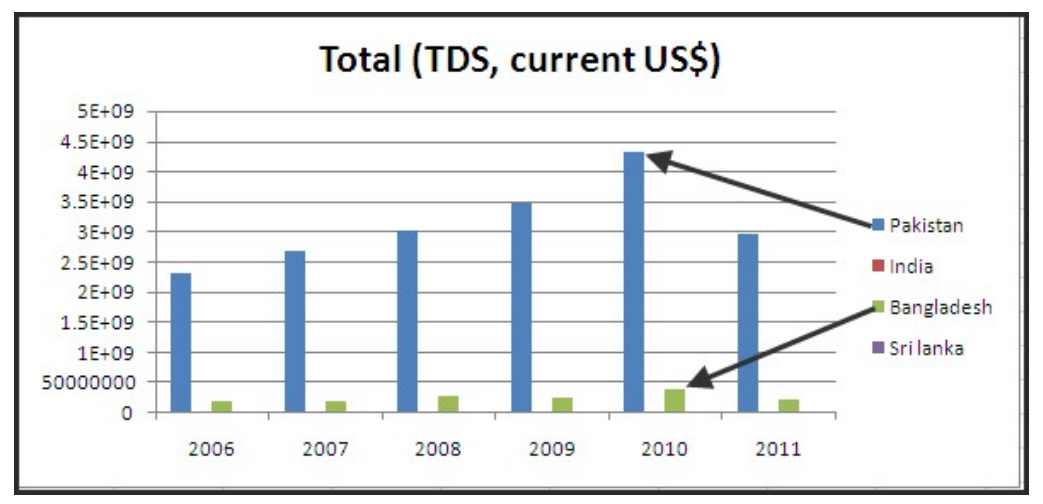

Figure 2.3: Debt Servicing on Total External Debt (TDS), current US\$ by South Asian Countries as Percentage of Gross Domestic Product (constant 2000 US\$) 1990-2011

Source: WDI.

On the one hand, these countries are still facing serious problems such as poverty, unemployment, poor infrastructure and health and illiteracy. But they are spending a large percentage of their GDPs on nonproductive activities. These might be crowding out growth as necessary expenditures and building physical and social infrastructure which can stimulate economic growth are not being made due to the nonavailability of resources.

Table 2 contains Government of Pakistan's expenditures on development, debt servicing, defense and current expenditures as percent of GDP.

Table 2: Breakdown of Expenditures (as \% of GDP)

\begin{tabular}{|l|l|l|l|l|}
\hline Year & $\begin{array}{l}\text { Devel } \\
\text { opme } \\
\text { nt }\end{array}$ & $\begin{array}{l}\text { Total } \\
\text { Debt }\end{array}$ & Defense & Current \\
\hline & $\begin{array}{l}\text { Expe } \\
\text { e }\end{array}$ & $\begin{array}{l}\text { Servic } \\
\text { ing }\end{array}$ & $\begin{array}{l}\text { Expendi } \\
\text { ture }\end{array}$ & $\begin{array}{l}\text { Expendit } \\
\text { ure }\end{array}$ \\
\hline $1999-00$ & 2.5 & 2.1 & 3.9 & 16.4 \\
\hline $2000-01$ & 2.1 & 2.3 & 3.1 & 15.3 \\
\hline $2001-02$ & 2.8 & 1.8 & 3.3 & 15.7 \\
\hline $2002-03$ & 2.6 & 1.9 & 3.3 & 16.2 \\
\hline $2003-04$ & 2.8 & 3.3 & 3.3 & 13.7 \\
\hline $2004-05$ & 3.5 & 1.6 & 3.2 & 13.3 \\
\hline $2005-06$ & 4.8 & 1.7 & 3.2 & 13.6 \\
\hline $2006-07$ & 5 & 1.5 & 2.9 & 15.8 \\
\hline $2007-08$ & 4.4 & 1.3 & 2.7 & 18.1 \\
\hline & & & & \\
\hline
\end{tabular}




\begin{tabular}{|l|l|l|l|l|}
\hline $2008-09$ & 3.8 & 2.1 & 2.6 & 16 \\
\hline $2009-10$ & 3.5 & 1.7 & 2.5 & 16.8 \\
\hline $2010-11$ & 2.8 & 1.3 & 2.5 & 16.1 \\
\hline $2011-12$ & 3.6 & 0.7 & 2.4 & 14.4 \\
\hline
\end{tabular}

Source: Pakistan Economic Survey 2011-12

\section{Data and Methodology}

Data are taken from various issues of the Pakistan Economic Survey, except the data on GDP which are from World Development Indicators (WDI) (in constant \$ 2000 US) for the period $1981-82$ to $2010-11$.

Most of the studies used Granger causality test to determine causality between defense expenditure and growth. This paper uses modified Granger Toda and Yamamoto
(1995) test for long run causality. Toda and Yamamoto makes Granger causality test easier because it does not need to test for cointegration or transform VAR into ECM (error correction model) and Toda and Yamamoto procedure avoids Granger causality testing problem with respect to size and power of unit root and co-integration test. By using the methodology, we will try to explore the impact of defense expenditure (DS), development expenditure (DE), and total debt spending (TDS) on GDP growth.

Figure 2.4: Model Fitting Flow Diagram

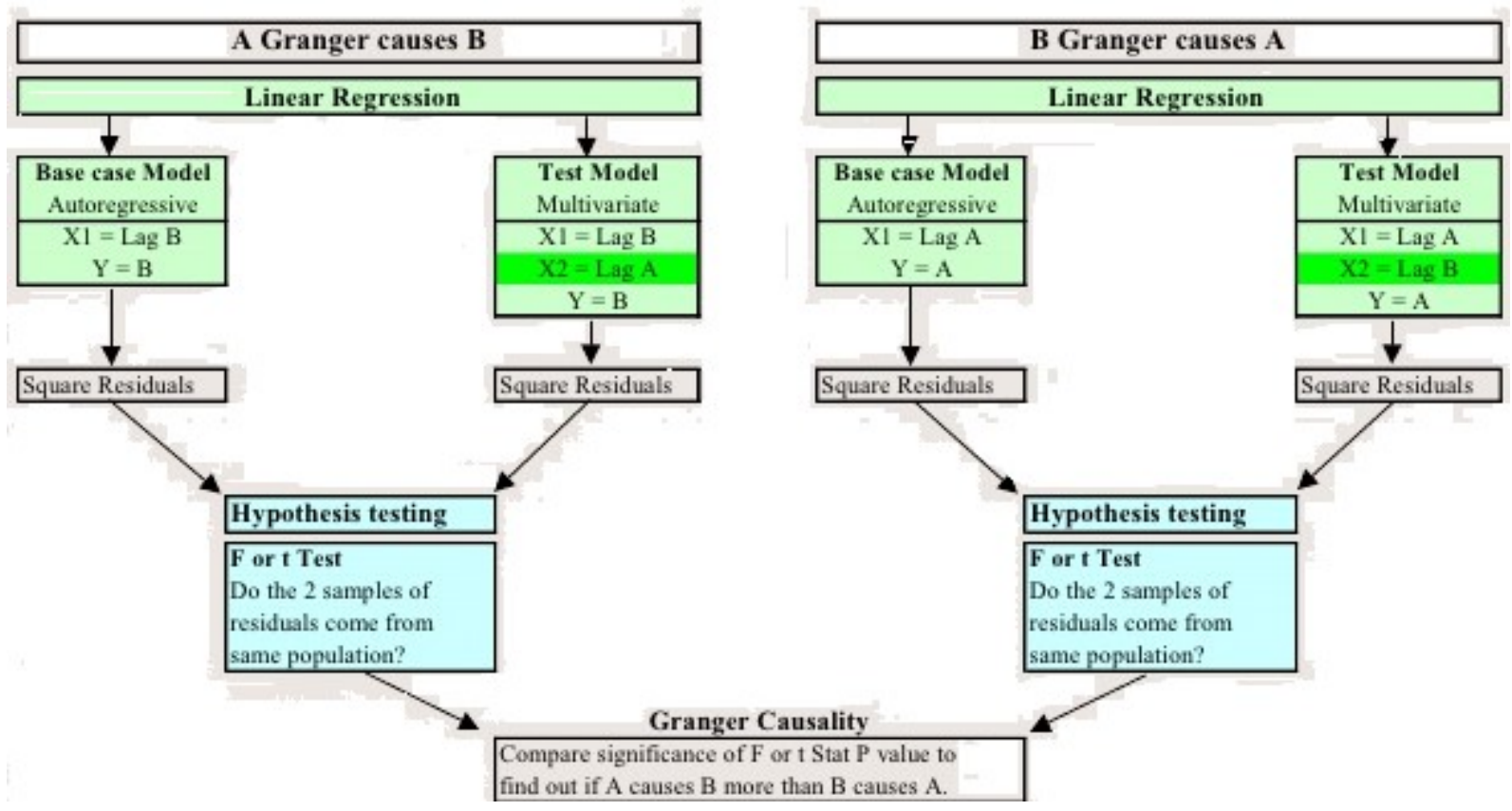

\section{Testing for Unit Root Problem}

First we examine the presence of unit root with augmented Dickey-Fuller (ADF) t-test (Dickey \& Fuller, 1997) for individual time series and their differences are used for the presence of unit root test. The Augmented Dickey Fuller (ADF) test was applied on each time series to find the existence of unit root where the null hypothesis states that unit 
root problem exists against the alternative hypothesis that there is no unit root problem. Table 3 presents the result of unit root test. The Table indicates that for all the variables we can not reject the null hypothesis i.e. unit root problem exists in the level form. But by first differencing the variables, the null hypothesis is rejected at the $1 \%, 5 \%$ and $10 \%$ significant levels revealing that the unit root problem does not exist.

Table 3 : Unit root test

\begin{tabular}{|l|l|l|}
\hline Variables & $\begin{array}{c}|c| \\
\text { ADF- }\end{array}$ & \\
\hline & Ltatistics & 1st Difference \\
\hline GDP & 0.317732 & $-2.743686^{* * *}$ \\
\hline DS & 0.076085 & $-4.257973^{*}$ \\
\hline DE & -0.060987 & $-3.062493^{* *}$ \\
\hline TDS & 0.749979 & $-4.696069^{*}$ \\
\hline $\log (\mathrm{CE})$ & -0.706382 & $-5.355757^{*}$ \\
\hline
\end{tabular}

Note: MacKinnon (1996), the optimal lags for conducting the ADF tests were determined by SBIC (Schwarz Bayesian information criteria).

${ }^{*}$ Denotes significance at $1 \%$ level

** Denotes significance at $5 \%$ level

*** Denotes significance at $10 \%$ level

where,

GDP= Gross Domestic Product.

DS= Defense Spending.

TDS=Total Debt Servicing.

$\mathrm{DE}=$ Development Expenditures.

$\log (C E)=\log$ of current expenditure.

\section{The Toda-Yamamoto Approach to Granger Causality Test}

Gujrati (1995) causality test is not valid if the variables are non-stationary and the $t$ statistic does not have standard distribution. Causality test is sensitive to model specification and the number of lags. Granger (1988) test is based on asymptotic theory; therefore, the critical values are only valid on stationary variables that are not bound together by a co-integrating relationship in the long run. Granger and Maekawa (1999) stated that when one or more time series are non-stationary, Granger-causality test by using F-statistics can lead to spurious causality.

Standard and Granger causality cannot be used in the presence of co-integration between two variables which has been modified by Toda and Yamamoto. Using this procedure, we can find the causality between integrated variables based on asymptotic theory. One advantage of Toda Yamamoto method is that we need not test for co-integration; the pretest bias can therefore be avoided.

To study the direction of causality between defense spending and GDP growth, we adopted today-Yamamoto version of the Granger causality test. Other variables for which causality needs to be tested are Total Debt Servicing 
(TDS) and Development Expenditure (DE) which can be strongly related to Gross Domestic Product (GDP).

$$
\begin{aligned}
& y_{t}=\alpha+\sum_{i=1}^{h+d} \beta_{i} Y_{t-i}+\sum_{j=i}^{k+d} \gamma_{J} X_{t-j}+\mu_{y t} \\
& X_{t}=\alpha+\sum_{i=1}^{h+d} \theta_{i} X_{t-i}+\sum_{j=i}^{k+d} \delta_{J} Y_{t-j}+\mu_{X t}
\end{aligned}
$$

Where, $\mathrm{h}$ and $\mathrm{k}$ are the optimal lag length of $Y_{t}$ and $X_{t}, d$ is maximal order of integration of the variables in the system and $\mu$ are error terms that are assumed to be white noise with zero mean, no autocorrelation and constant variance. We add the maximum order of integration to the number of lags and carry out a Wald test for the first Pvariables only with P-degree of freedom. For Toda-Yamamoto, the null hypothesis states that there is no causality whereas

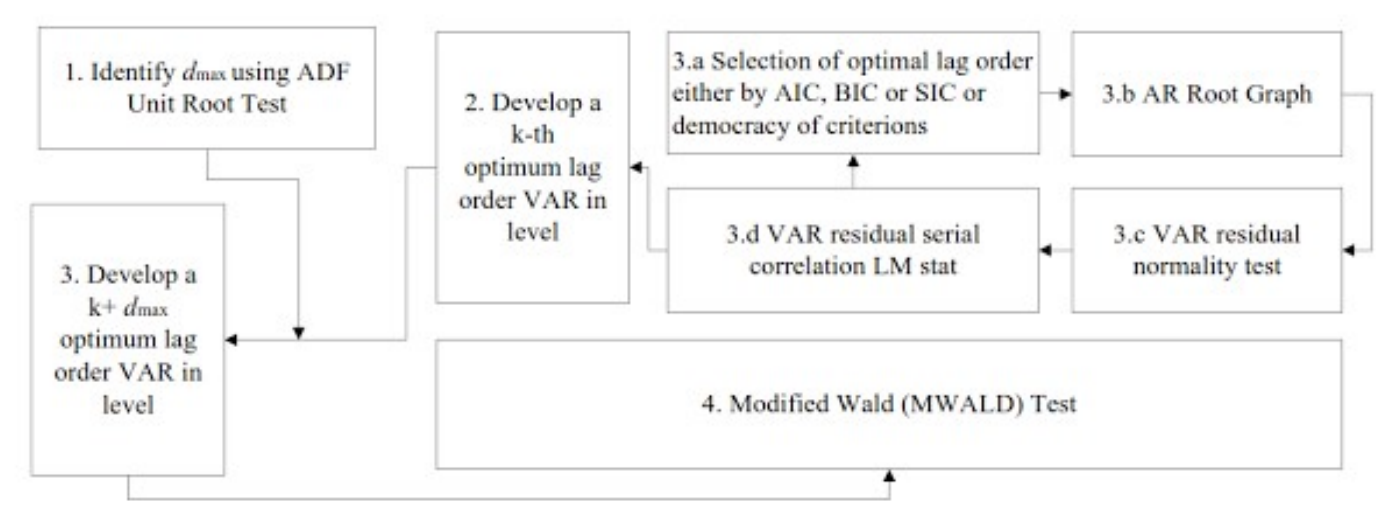

Figure 2.5: Model Fitting Flow Diagram
Toda and Yamamoto (1995) Augmented Granger causality test is based on the following equations:

the alternative states that there is causality.

The optimum lag length of VAR in models is $k=2$ based on SIC criterion. However, all the variables are stationary in first difference. This means that $d \max =1$. Therefore $k+d m a x=2+1=3$ lags. The probability values of $\chi 2$ statistics are given; the low $P$ values suggest that we reject the null hypothesis. 
Table 4: Toda-Yamamoto Causality Test

\begin{tabular}{|l|l|l|l|l|l|l|}
\hline Variables & \multicolumn{1}{|c|}{$\mathbf{X}^{\mathbf{2}}$} & \multicolumn{1}{|c|}{ P-Value } & \multicolumn{1}{|c|}{ Variables } & \multicolumn{1}{|c|}{$\mathbf{X}^{\mathbf{2}}$} & P-Value & Causality Direction \\
\hline GDP to DS & 6.222100 & 0.0446 & DS to DGP & 2.283133 & 0.5158 & GDP $\rightarrow$ DS \\
\hline GDP to DE & 20.75764 & 0.0000 & DE to GDP & 24.82207 & 0.0000 & GDP $\leftrightarrow$ DE \\
\hline GDP to TDS & 0.969092 & 0.6160 & TDS to GDP & 25.95178 & 0.0000 & GDP $\rightarrow$ TDS \\
\hline GDP to $\log (\mathrm{CE})$ & 9.023334 & 0.0110 & $\log (\mathrm{CE})$ to GDP & 10.65070 & 0.0138 & GDP $\leftrightarrow \log (\mathrm{CE})$ \\
\hline
\end{tabular}

\section{Empirical Results}

The Toda Yamamoto causality test suggests that Gross Domestic Product (GDP) causes Defense Spending (DS) without feedback or unidirectional causality between Gross Domestic Product (GDP) and Defense Spending (DS). This means that high and stable economic growth leads to heavy defense spending, i.e. the Government of Pakistan increases the defense budget when economic growth increases. Kollias (1997) argues that high growth rate counties may divert their resources from defense to other productive economic activities. However, development expenditure (DE) and log of current expenditure (CE) causes gross domestic product (GDP) with feedback or bidirectional causality existing between the two, or we can say development expenditure and economic growth causes each other. Whereas, Gross Domestic Product (GDP) causes Total Debt Servicing (TDS) without feedback or unidirectional causality between the two. That is, economic growth causes debt servicing in the case of Pakistan.

\section{Conclusion and Policy Implications}

The current research used annual data for Pakistan, we examined the direction of causality between economic growth and expenditure based on Toda Yamamoto (1995). On the basis of empirical results, we conclude that in the case of Pakistan there is a unidirectional causality between GDP and DS. Furthermore, there is a bidirectional causality between development expenditure (DE) and economic growth (GDP), bidirectional causality between the log of current expenditure (CE) and economic growth (GDP). While economic growth (GDP) causes total debt servicing (TDS) but debt servicing does not cause GDP. defense expenditure was funded by taking a route to higher and deepening budget deficit. It is observed, after 9/11, high defense spending is badly needed in the state of Pakistan. However, due to high external debt and slow economic growth, there are hugge obstacles for the defense budget. To maintain a strong armed force in order to control terrorism within a border and across borders. The Massive defense budget is not only due to 9/11, it was inherited in Pakistan's budget since establishment and was strongly recommended after Dhaka's partition. Other research studies discussed the existence of long run negative relationship between defense spending and economic growth in 1972-2009. The study referred to defense expenditure as the real opportunity cost and the country faces a tradeoff between defense spending and the public expenditures. Some argue that high military expenditure is a problem for a country with low income. (Khan ,2004). Pradhan(2010) found the relationship between long run relationship is not only in the case of Pakistan, but exists for all four Asian countries, namely: China, India, 
Nepal and Pakistan. This is an indication of the causality between spending and economic growth. Moreover, this also points that changes in the defense spending of a country can cause the defense spending of another country.

Empirical finding highly suggested for policy recommendation, Pakistan badly needed to be self-sufficient in domestic defense industry, which can lead to curtail in defense budget, it will create employment resources and funds will be available for developing programs. Although ,because of political and regional instability bound this region to pick guns not butter from guns verses butter dilemma. Although scarcity and inefficiency in productive sectors indicated to choose butter instead of guns. Internal and external terrorism are not allowed to curtail in defense budget, specially in the current situation where India is trying to create another big dispute against Pakistan. Mirza, Jaspal and Malik (2015) suggested Pakistan's defense indusrty needs to be self-sufficient with long-run sustainability by providing essential military equipment to armed force, through this import expenditure will reduce and it can provide support to overall military spending. Furthermore, another policy which needs to be done is to achieve efficiency level or increase efficiency in all economic sectors, by this Pakistan will be able to get rid of IMF's fund, which is the root cause of less developing expenditure. Künü, Hopoğlu and Bozma (2016), an empirical finding suggested increase in spending on public sectors and development of domestic defense industry in a way like Iran, Israel and Turkey.

This research only checked the direct effects of defense spending on economic growth. It ignored possible indirect effects, such as employment, investment, law and order and political aspects of defense spending. Economic growth can limit the growth of public debt burden and expenses and avoid future debt traps and stronger taxation mechanism.

\section{Acknowledgement}

This research was supported/partially supported by []. I thank Dr Shahida Wizarat, Dean CESD, Director Research, Chief Editor PBR, HOD Economics, IOBM, Karachi and Dr. Muhammad Shahbaz Principal Research Officer,department of Management Science, who provided insight and expertise that greatly assisted the research, although they may not agree with all of the interpretations/conclusions of this paper.

\section{References}

1. Al-jarrah (2005): "Defense Spending and Economic Growth in an Oil-Rich Country the Case of Saudi Arabia", Pakistan Economic and Social Review, Volume XLIII, No. 2 (Winter 2005), pp. 151-166.

2. Brasoveanu (2010), "The Impact Of Defense Expenditure On Economic Growth, In Romanian", journal of economic forecasting volume 13, no. 4 /2010,university of economic studies, bucharest, finance department, email:laura_obreja@yahoo.com

3. Cholifihani Muhammad," A Cointegration Analysis Of Public Debt Service And Gdp In Indonesia", Journal of Management and Social Sciences, Vol. 4, No. 2, (Fall 2008) 6881.

4. d'Agostino, G., Dunne, J. P., \& Pieroni, L. (2010). Assessing the effects of military expenditure on growth. Department of Economics, University of the West of England.

5. d'Agostino, G., Dunne, J. P., \& Pieroni, L. (2010). Assessing the effects of military expenditure on growth. Department of Economics, University of the West of England.

6. Dandan. M. Mwafaq , "Government Expenditures And Economic Growth In Jordan", 2011 International Conference on Economics and Finance Research(IPEDR), vol.4 (2011) (C) (2011) IACSIT Press, Singapore. 
7. Dimitraki. O. And Liu G.( 2011), "THE MILITARY EXPENDITURE -ECONOMIC GROWTH NEXUS: EVIDENCE FROM CHINA, 1950-2011", March 2011, Department of Economics and Finance Brunel UniversityUxbridge UB8 3PH, Email: Ourania.Dimitraki@brunel.ac.uk.

8. Dogan Ergun, "Government Expenditure and National Income: Causality Tests For Five South East Asian Countries", (E-mail: ergun.dogan@buseco.monash.edu.my), Monash University, Malaysia Tuck Cheong Tang, Monash University, Malaysia International Business \& Economics Research Journal - October 2006 Volume 5, Number 10.

9. Dunne (2000), "The Economic Effects of Military Expenditure in Developing Countries", Economics Group Middlesex University Business School, The Burroughs, Hendon, London, NW4 4B.(May 2000).

10.Dunne (2009), "Defense Spending and Development"' Department of Economics, British University in Egypt and University of the West of England John2.Dunne@uwe.ac.uk.

11.Dunne (2010), "Military Spending and Economic Growth in Sub Saharan Africa", School of Economics, University of the West of England, Bristol BS16 1QY, UK and SALDRU, University of Cape Town Email: John2.Dunne@uwe.ac.uk, February 2010.

12.Fan Shenggen and Rao Neetha,"Public Spending In Developing Countries: Trends, Determination, And Impact", Environment and Production Technology Division, EPTD Discussion Paper No. 99

13.Farhani, S. (2016). Usage of Military Spending, Debt Servicing and Growth for Dealing with Emergency Plan of Indian External Debt. World Academy of Science, Engineering and Technology, International Journal of Social, Behavioral, Educational, Economic, Business and Industrial Engineering,10(3), 787-798.
14.Farzanegan. R.(2012), "Military Spending and Economic Growth: The Case of Iran",http://www.unimarburg.de/fb02/mak ro/forschung/magkspapers/index_html\%28 magks\%29 Coordination: Bernd Hayo • Philipps-University Marburg Faculty of Business Administration an Economics Universitätsstraße 24, D-35032 Marburg, Tel: +49-6421-2823091, Fax: +49-6421 2823088,e- mail: hayo@wiwi.unimarburg.de

15.Gujarati, D. (1995): Basic Econometrics, 3rd Edition, McGraw-Hill, New York.

16. Habibullah, Law \& Affizzah (2008),"Defense spending and economic growth in Asian economies: A panel errorcorrection approach", Online at http://mpra.ub.uni-muenchen.de/12105/ MPRA Paper No. 12105, posted 12. December $2008 / 10: 29$

17.Hasan. K (2004), "Defense Expenditure and Macroeconomic Stabilization: Causality Evidence from Pakistan", SBP Working Paper Series No. 06 December, 2004.

18.Haseeb, M., Bakar, N. A. A., Azam, M., Hassan, S., \& Hartani, N. H. (2014). The macroeconomic impact of defense expenditure on economic growth of Pakistan: An econometric approach. Asian Social Science, 10(4), 203.

19.Hou, N. (2010). Arms race, military expenditure and economic growth in India(Doctoral dissertation, University of Birmingham).

20.Kalim, R., \& Hassan, M. S. (2013). Military expenditure and poverty in Pakistan: a complex phenomenon. In Proceedings of 3rd International Conference on Business Management (ISBN: 978-969-9368-07-3), School of Business and Economics, University of Management and Technology, Lahore, Pakistan.

21.Khan, M. U. H. (2004). Defense expenditure and macroeconomic stabilization: Causality evidence from 
Pakistan. State Bank of Pakistan Working Paper, 6.

22.Khilji and Mahmood (1997), "Military Expenditures and Economic Growth in Pakistan ", The Pakistan Development Review 36 : 4 Part II (Winter 1997) pp. 791-808.

23.Künü, S., Hopoglu, S., \& Bozma, G. (2016). Conflict, Defense Spending and Economic Growth in the Middle East: A Panel Data Analysis. International Journal of Economics and Financial Issues, 6(1).

24.Looney and Frederickson (1990), "The Economic Determinants Of Military Expenditure In Selected East Asian Countries", contemporary southeast asia, volume 11, number4, march 1990.Models: Some Finite Sample Evidence" Journal of Econometrics, 86, 55-95

25.Mirza, M. N. (2015). Military Spending and Economic Growth in Pakistan.Margalla Papers, 19.

Ogunmuyiwa M.S, "Does External Debt Promote Economic Growth in Nigeria?", Current Research Journal of Economic Theory 3(1): 29-35, 2011,ISSN: 2042-485X, (C) Maxwell Scientific Organization, 2011.

26.Pradhan (2010)," Defense Spending and Economic Growth in China, India, Nepal and Pakistan: Evidence from Cointegrated Panel Analysis", www.ccsenet.org/ijef International Journal of Economics and Finance Vol. 2, No. 4; November 2010,Vinod Gupta School of Management, Indian Institute of Technology, Kharagpur, India E-mail: rudrap@vgsom.iitkgp.ernet.in

27.Pradhan (2010),"Modelling the nexus between defense spending and economic growth in asean- 5: Evidence from cointegrated panel analysis",African Journal of Political Science and International Relations Vol. 4(8), pp. 297-307, November 2010 Available online at http://www.academicjournals.org/ajpsir ISSN 1996-0832 @2010 Academic Journals.
28.Pradhan, R. P. (2010). Defense spending and economic growth in China, India, Nepal and Pakistan: Evidence from cointegrated panel analysis.International Journal of Economics and Finance, 2(4), 65.

29.Pradhan. R. (2010), "Defense Spending and Economic Growth in China, India, Nepal and Pakistan: Evidence from Cointegrated Panel Analysis", International Journal of Economics and Finance Vol. 2, No. 4; November 2010, www.ccsenet.org/ijef.

30. Rehman, Iqbal ,Siddiqi "CointegrationCausality Analysis between Public Expenditures and Economic Growth in Pakistan", European Journal of Social Sciences - Volume 13, Number 4 (2010)

31.Sevitenyi L. Nkwatoh,"Government Expenditure And Economic Growth In Nigeria: An Empirical Investigation (19612009)", The Journal of Economic Analysis, Year 2012, Volume Iii, Issue I, Pages 38-51.

32.Shabbir S, (2008) Does External Debt Affect Economic Growth: Evidence from Developing Countries. International Research Journal of Finance and Economics, pp. 14502887.

33.Shah M. Hasan and Pervin Shahida,"External Public Debt And Economic Growth: Empirical Evidence From Bangladesh, 1974 To 2010", ISSN-L: 22239553, ISSN: 2223-9944,Vol. 3, No. 2, September 2012.

34.Shahbaz, M., Afza, T., \& Shabbir, M. S. (2013). Does defense spending impede economic growth? Cointegration and causality analysis for Pakistan.Defense and Peace Economics, 24(2), 105-120.

35.Shenggen Fan and Anuja Saurkar, "Public Spending In Developing Countries:Trends, Determination, And Impact".

36.SIPRI military expenditure database. 
37.Tekeoglu, E. (2008). Defense expenditure and economic growth: empirical study on case of Turkey.

38.Toda, H. Y. and Yamamoto, T., 1995, "Statistical inference in vector autoregressions with possibly integrated processes", Journal of Econometrics, 66, pp. 225-250.

39.World development index (WDI) database.

42.

\section{Appendix}

Gross Domestic Product by Country (constant 2000 US\$) from 1990-2011

\begin{tabular}{|c|c|c|c|c|}
\hline Year & Pakistan & India & Bangladesh & Sri Lanka \\
\hline 1990 & 50248972481 & $2.76 \mathrm{E}+11$ & 29489968538 & 9821725438 \\
\hline 1991 & 52792358269 & $2.79 E+11$ & 30474743435 & 10273524808 \\
\hline 1992 & 56860483455 & $2.95 \mathrm{E}+11$ & 32010406325 & 10725559900 \\
\hline 1993 & 57859947294 & $3.09 E+11$ & 33474682526 & 11465623533 \\
\hline 1994 & 60022413964 & $3.29 E+11$ & 34842024065 & 12107698451 \\
\hline 1995 & 63001091770 & $3.54 \mathrm{E}+11$ & 36558011931 & 12773621865 \\
\hline 1996 & 66054490892 & $3.81 \mathrm{E}+11$ & 38247711533 & 13259019496 \\
\hline 1997 & 66724545016 & $3.96 \mathrm{E}+11$ & 40308326777 & 14108314847 \\
\hline 1998 & 68426177246 & $4.21 \mathrm{E}+11$ & 42415457211 & 14771179512 \\
\hline 1999 & 70930666164 & $4.57 \mathrm{E}+11$ & 44480763467 & 15406424815 \\
\hline 2000 & 73952374970 & $4.75 \mathrm{E}+11$ & 47124925462 & 16330810304 \\
\hline 2001 & 75418468995 & $4.98 \mathrm{E}+11$ & 49610300682 & 16078438393 \\
\hline 2002 & 77850284715 & $5.18 \mathrm{E}+11$ & 51800799317 & 16715893245 \\
\hline 2003 & 81623159361 & $5.59 \mathrm{E}+11$ & 54523446362 & 17708862282 \\
\hline 2004 & 87637620104 & $6.03 E+11$ & 57942340648 & 18673120685 \\
\hline 2005 & 94357063094 & $6.59 \mathrm{E}+11$ & 61393084272 & 19838649830 \\
\hline 2006 & $1.00 \mathrm{E}+11$ & $7.20 \mathrm{E}+11$ & 65463038830 & 21359771931 \\
\hline 2007 & $1.06 \mathrm{E}+11$ & $7.90 \mathrm{E}+11$ & 69670899876 & 22811733077 \\
\hline 2008 & $1.08 \mathrm{E}+11$ & $8.21 \mathrm{E}+11$ & 73983829245 & 24169041086 \\
\hline 2009 & $1.11 \mathrm{E}+11$ & $8.88 \mathrm{E}+11$ & 78231358239 & 25024372773 \\
\hline 2010 & $1.15 \mathrm{E}+11$ & $9.73 E+11$ & 82979485251 & 27030316336 \\
\hline 2011 & $1.19 \mathrm{E}+11$ & $1.04 \mathrm{E}+12$ & 88545829824 & 29260877188 \\
\hline
\end{tabular}

Sabeen Anwar (2017), Journal of Economics Studies and Research, DOI: 10.5171/2017.280356
40.Yamada, T. and Toda, H.Y. (1998):"Inference in possibly Integrated Vector Autoregressive.

41.Zaman, K., Iqtidar, A. S., Khan, M. M., \& Ahmad, M. (2013). Impact of military expenditure and economic growth on external debt: new evidence from a panel of SAARC countries. Journal of Economic and Social Studies,3(2), 131-149. 
Data source: WDI

Total Debt Servicing on External Debt (TDS) current US\$ by Country as Percentage of Gross Domestic Product (constant 2000 US\$) 1990-2011

\begin{tabular}{|l|l|l|l|l|}
\hline Year & Pakistan & India & Bangladesh & Sri Lanka \\
\hline $\mathbf{1 9 9 0}$ & 95573316.58 & 8518.392257 & 8634129.279 & 4455.724342 \\
\hline $\mathbf{1 9 9 1}$ & 98479457.56 & 7979.044762 & 7426039.303 & 5609.504381 \\
\hline $\mathbf{1 9 9 2}$ & 116373192.8 & 6995.863743 & 10513197.9 & 4309.231163 \\
\hline $\mathbf{1 9 9 3}$ & 2383078000 & 329.7298704 & 179700734.8 & 214.0853794 \\
\hline $\mathbf{1 9 9 4}$ & 3448584000 & 236.0768942 & 311546372.5 & 133.708506 \\
\hline $\mathbf{1 9 9 5}$ & 3215513000 & 244.3690944 & 242472151.1 & 186.8412508 \\
\hline $\mathbf{1 9 9 6}$ & 3286142000 & 247.7467498 & 296871301.2 & 129.5891514 \\
\hline $\mathbf{1 9 9 7}$ & 4083292000 & 192.4359071 & 307908752 & 135.2881324 \\
\hline $\mathbf{1 9 9 8}$ & 2297771000 & 354.3133759 & 207581494.3 & 218.2458516 \\
\hline $\mathbf{1 9 9 9}$ & 2944827000 & 266.8312943 & 222060535.1 & 173.2469031 \\
\hline $\mathbf{2 0 0 0}$ & 2864219000 & 284.2418823 & 258754619.1 & 160.988044 \\
\hline $\mathbf{2 0 0 1}$ & 3001020000 & 261.8349761 & 226297880 & 200.1954238 \\
\hline $\mathbf{2 0 0 2}$ & 2894031000 & 281.3138491 & 261447846.4 & 147.1471291 \\
\hline $\mathbf{2 0 0 3}$ & 3079454000 & 255.1660132 & 232212351.7 & 179.3892517 \\
\hline $\mathbf{2 0 0 4}$ & 4286281000 & 189.9387838 & 387224233.7 & 116.9962932 \\
\hline $\mathbf{2 0 0 5}$ & 2447455000 & 321.0567712 & 184555210.5 & 208.4541525 \\
\hline $\mathbf{2 0 0 6}$ & 2321391000 & 350.7082607 & 209715333.9 & 198.6330671 \\
\hline $\mathbf{2 0 0 7}$ & 2674985000 & 293.7481892 & 201712562.6 & 224.595828 \\
\hline $\mathbf{2 0 0 8}$ & 3011623000 & 270.3296528 & 272071151.8 & 141.4016141 \\
\hline $\mathbf{2 0 0 9}$ & 3478474000 & 225.8956082 & 262301248.2 & 158.8112916 \\
\hline $\mathbf{2 0 1 0}$ & 4311330000 & 188.8352318 & 389487169.8 & 116.3165401 \\
\hline $\mathbf{2 0 1 1}$ & 2958601000 & 265.5890402 & 223099191 & 172.4403385 \\
\hline
\end{tabular}

Data source: WDI

Final consumption expenditure etc. by Country as Percentage of Gross Domestic Product (constant 2000 US\$) from 1990-2011

\begin{tabular}{|l|l|l|l|l|}
\hline year & Pakistan & India & Bangladesh & Sri Lanka \\
\hline $\mathbf{1 9 9 0}$ & 88.89751 & 76.46664911 & 90.35441689 & 85.67641648 \\
\hline $\mathbf{1 9 9 1}$ & 82.53439 & 77.50793902 & 88.66864138 & 87.24355101 \\
\hline $\mathbf{1 9 9 2}$ & 82.93252 & 76.49201003 & 87.45561836 & 84.98764352 \\
\hline $\mathbf{1 9 9 3}$ & 85.31613 & 78.69703755 & 87.14021686 & 83.98826979 \\
\hline
\end{tabular}




\begin{tabular}{|l|l|l|l|l|}
\hline $\mathbf{1 9 9 4}$ & 83.2156 & 77.1028351 & 86.46022078 & 84.77785606 \\
\hline $\mathbf{1 9 9 5}$ & 84.16729 & 75.10584644 & 87.36043346 & 84.70870297 \\
\hline $\mathbf{1 9 9 6}$ & 85.52727 & 79.08177591 & 87.61566162 & 84.67820467 \\
\hline $\mathbf{1 9 9 7}$ & 86.76916 & 76.70335205 & 85.30188385 & 82.67520188 \\
\hline $\mathbf{1 9 9 8}$ & 83.33094 & 78.11988932 & 83.31641398 & 80.87056207 \\
\hline $\mathbf{1 9 9 9}$ & 86.04802 & 75.69036936 & 83.27201406 & 80.49357845 \\
\hline $\mathbf{2 0 0 0}$ & 84.02033 & 77.36121483 & 82.22333293 & 82.56576211 \\
\hline $\mathbf{2 0 0 1}$ & 84.0561 & 75.81362208 & 83.03154768 & 84.23220648 \\
\hline $\mathbf{2 0 0 2}$ & 83.50763 & 76.49251042 & 81.62356653 & 84.479263 \\
\hline $\mathbf{2 0 0 3}$ & 82.64854 & 75.37997379 & 82.41616794 & 84.40515828 \\
\hline $\mathbf{2 0 0 4}$ & 82.38832 & 69.30063532 & 81.32545842 & 84.09051669 \\
\hline $\mathbf{2 0 0 5}$ & 84.79304 & 68.46526251 & 81.93724424 & 82.10277147 \\
\hline $\mathbf{2 0 0 6}$ & 85.84835 & 67.28715193 & 81.62038199 & 83.02421495 \\
\hline $\mathbf{2 0 0 7}$ & 84.5921 & 65.9802086 & 82.46155526 & 82.42436893 \\
\hline $\mathbf{2 0 0 8}$ & 88.98126 & 69.54158805 & 84.20396451 & 86.1336895 \\
\hline $\mathbf{2 0 0 9}$ & 89.33529 & 69.25243827 & 82.75254914 & 82.05853959 \\
\hline $\mathbf{2 0 1 0}$ & 90.29953 & 68.32626208 & 82.19631662 & 80.72990794 \\
\hline $\mathbf{2 0 1 1}$ & 91.99932 & 67.74163042 & 83.55875368 & 84.61531642 \\
\hline
\end{tabular}

Data source: WDI 